\title{
Capra hircus
}

National Cancer Institute

\section{Source}

National Cancer Institute. Capra hircus. NCI Thesaurus. Code C161015.

The domesticated goat species, Capra hircus. 